\title{
The rise of Facebook-based communication in the energy sector
}

\author{
A longitudinal analysis of German and Austrian utility companies
}

\author{
Sebastian Martin ${ }^{1}$
}

Published online: 3 June 2016

(C) The Author(s) 2016. This article is available at SpringerLink with Open Access

\begin{abstract}
In the case of public utilities, the development of stakeholder communication through Facebook is not focused in the existing body of literature. Yet, it is especially these developments that are essential for scholars and practitioners as they highlight the way stakeholder communication in the energy sector will change. The aim of this paper is to contribute to this lack of research by investigating developments in the ways German and Austrian public utilities use Facebook to communicate. Responding to the research objectives, two empirical studies were conducted. In 2014 as well as 2015 an online survey was sent to 850 German and 30 Austrian utilities. The results highlight the rising importance of Facebook in the energy sector. The share of public utilities using Facebook is constantly increasing. Additionally, during the twelve months investigated, the interactivity and frequency of Facebook-based communication rose. Utilities are progressively willing to invest more personnel and monetary resources to administer their accounts. As the numbers of fans increase, users seem to value the information provided by utilities on Facebook.
\end{abstract}

Keywords Communication development - Facebook ·

Public utilities $\cdot$ Social media $\cdot$ Stakeholder dialog

\section{Die Entwicklung Facebook-basierter Kommunikation in der Energiewirtschaft}

Eine Längsschnittstudie Deutscher und Österreichischer Energieversorger

Prof. Dr. Sebastian Martin

Sebastian.Martin@fh-linz.at

1 University of Applied Sciences Upper Austria, Garnisonstrasse 21, 4020 Linz, Austria
Zusammenfassung Zunehmend nutzen öffentliche Unternehmen Facebook zur gezielten Stakeholder-Kommunikation. Hierzu zählen auch öffentliche Energieversorger. Bislang gibt es jedoch nur wenige Untersuchungen, die eine Facebook-basierte Kommunikation von Energieversogern thematisieren. Keine der Untersuchungen fokussiert mögliche Veränderungen der Facebook-Kommunikation im Zeitverlauf. Ziel dieser Studie ist es Erkenntnisse zur Entwicklung der Facebook-Kommunikation in der Energiewirtschaft zu generieren. Hierzu wurden zwei Befragungen mit jeweils 850 deutschen und 30 österreichischen Energieversorgern im zeitlichen Abstand von 12 Monaten durchgeführt. Als Ergebnis der Untersuchung kann eine steigende Bedeutung von Facebook in der Energiewirtschaft festgestellt werden. Im beobachteten Zeitraum hat sich der Anteil von Unternehmen die Facebook für ihre StakeholderKommunikation verwenden erhöht. Zudem ist eine Zunahme in der Häufigkeit und Interaktivität der Kommunikation erkennbar. Auch Investitionen in Form von personellen und monetären Ressourcen, welche für den Facebook-Auftritt aufgewendet werden, nehmen zu. Steigende Fanzahlen scheinen ein Hinweis darauf sein, dass die Facebook-Nutzer das Kommunikationsangebot zunehmend annehmen.

\section{Introduction}

Facebook offers individuals as well as companies a way to connect and interact virtually. As far as the private sector is concerned, a large amount of literature examines the potential benefits as well as risks of Facebook activity (Pietsch 2012; Wingenter 2013; Haigh et al. 2013). As well as for the public sector, the relevance of Facebook is increasing (Oliveira and Welch 2013; Mossberger et al. 2013; Meijer and Thaens 2013). "Agencies and departments on all lev- 
els of government are adding Facebook [...] buttons to their otherwise static - infrequently updated - websites" (Mergel 2010, p. 7). Regarding the public sector, current Facebook studies mainly focus on government agencies (Hofmann et al. 2013; Mergel 2013a; Vicente and Novo 2014). The use of Facebook in other public organizations has barely been investigated (Criado et al. 2013).

In Germany and Austria, public utilities in particular are being confronted with far-reaching socio-political changes, such as the departure from nuclear and fossil-fuel energy sources (Witt 2013; Dechange and Friedrich 2013; Federal Ministry of Education and Research 2014). In this challenging environment, stakeholder theory emphasizes the importance of communication between the utilities and their various stakeholders (Freeman 1984; Pedersen et al. 2013). Such a communication process might be supported by the use of Facebook. However, the existing body of literature insufficiently reflects stakeholder communication of public utilities through Facebook. None of the studies focuses on developments of Facebook based communication. Yet, especially these developments are essential for scholars as well as practitioners, as they highlight the way stakeholder communication might change in the energy sector. The aim of this paper is to contribute to this lack of research by providing data about the engagement of German and Austrian public utilities in Facebook over a period of one year. Special focus is put on developments regarding:

- the share of utilities which use Facebook for stakeholder communication,

- the interactivity and frequency of Facebook communication,

- the monetary and personnel resources deployed for Facebook communication,

- communication outcomes.

Research results will illustrate essential communication developments in the energy sector as well as highlight implications for both researchers and practitioners. To address the research objectives, the paper is structured as follows: After the introduction (Sect. 1), Section 2 introduces stakeholder theory as the theoretical framework for the study. The theoretical basis highlights the importance of stakeholder communication in the context of the energy sector. The methodological approach is described in Section 3, and the empirical results are illustrated in Section 4. A discussion, the conclusion, limitations, and implications for further research are presented in Section 5 and 6.

\section{Stakeholder theory in the context of the energy sector}

According to stakeholder theory, utilities should actively manage relationships with a wide variety of stakeholders (Freeman 1984) as these stakeholders may strongly impact the company and its objectives (Donaldson and Preston 1995; Wall and Greiling 2011). Stakeholder theory recommends collecting the relevant stakeholder information and integrating this knowledge into the corporate decision making process (Freeman and Evan 1990). A stakeholder dialog can be seen as an appropriate form of such data collection. On the basis of a dialog, insights into stakeholders' expectations and criticism might be gained. Additionally, a dialog offers the company an opportunity to explain its objectives and behavior to the various groups of stakeholders (Schulten 2012; Pedersen et al. 2013).

As the most popular social network in 2014, Facebook counted around 28 million German and about three million Austrian users (statista 2014a, 2014b). The social network offers a way for direct and indirect communication (Kreutzer and Hinz 2010; Yang and Lin 2013; Spillecke 2013; Mergel 2013b). Organizations as well as single online users are able to reach a broad community of Facebook users by highlighting specific aspects, ideas or concerns (Wallsten 2007; Merilainen and Vos 2011). "[W]e all tend to pay closer attention to those things our friends and trusted colleagues point to as being interesting, useful, or otherwise noteworthy." (Mergel and Greeves 2012, p. 38). The spread of recommendations through Facebook is not limited to direct contacts. Indirect contacts, meaning the contacts linked to the direct contacts but not to the companies' Facebook page, might as well be informed. This tremendously expands the number of possible recipients (Mergel 2010; Mergel and Greeves 2012). In this way Facebook provides a platform which might be used to influence public and political opinions (Wallsten 2007; Fieseler et al. 2010; Merilainen and Vos 2011; La Rosa 2014).

Stakeholder theory highlights the importance of stakeholder communication (Freeman 1984). German and Austrian public utilities may communicate with their various groups of stakeholders through Facebook (Oliveira and Welch 2013; Mossberger et al. 2013). As the number of Facebook users in both countries has constantly been increasing over the years (statista 2014a, 2014b), these media have been gaining importance as a potential instrument which can be used for stakeholder communication. Utility companies might increasingly become aware of such communication opportunities associated with Facebook. Therefore more and more utilities might actively be engaged in Facebook based stakeholder communication. 
Fig. 1 Ownership and number of employees (indicator of company size) of the participating utilities

\begin{tabular}{|c|c|c|c|c|c|}
\hline \multicolumn{6}{|l|}{ Ownership } \\
\hline & \multicolumn{2}{|c|}{2014} & \multicolumn{3}{|c|}{2015} \\
\hline & $\begin{array}{c}\text { number of } \\
\text { utilities }\end{array}$ & percentage & $\begin{array}{c}\text { number of } \\
\text { utilities }\end{array}$ & \multicolumn{2}{|c|}{ percentage } \\
\hline $\begin{array}{l}\text { entirely } \\
\text { public }\end{array}$ & 39 & $44 \%$ & 78 & $52 \%$ & \\
\hline $\begin{array}{l}\text { completely in private } \\
\text { ownership }\end{array}$ & 11 & $13 \%$ & 23 & $15 \%$ & \\
\hline \multirow{5}{*}{$\begin{array}{l}\text { public share }>50 \% \\
\text { public share }<50 \% \\
\text { public share }=50 \% \\
\text { not specified }\end{array}$} & 36 & $41 \%$ & 48 & $32 \%$ & \\
\hline & 25 & $70 \%$ & 27 & & $56 \%$ \\
\hline & 7 & $19 \%$ & 9 & & $19 \%$ \\
\hline & 3 & $8 \%$ & 3 & & $6 \%$ \\
\hline & 1 & $3 \%$ & 9 & & $19 \%$ \\
\hline \multirow[t]{2}{*}{ not specified } & 2 & $2 \%$ & 0 & $0 \%$ & \\
\hline & 88 & $100 \% \quad 100 \%$ & 149 & 100 & $100 \%$ \\
\hline
\end{tabular}

\begin{tabular}{|c|c|c|c|c|}
\hline \multirow[t]{2}{*}{ Number of employees } & & & & \\
\hline & $\begin{array}{c}\text { number of } \\
\text { utilities }\end{array}$ & percentage & $\begin{array}{c}\text { number of } \\
\text { utilities }\end{array}$ & percentage \\
\hline 1-49 employees & \multirow{3}{*}{59} & \multirow{3}{*}{$67 \%$} & 30 & $20 \%$ \\
\hline 50-249 employees & & & 38 & $26 \%$ \\
\hline 250-599 employees & & & 21 & $14 \%$ \\
\hline 600-1200 employees & 13 & $15 \%$ & 25 & $17 \%$ \\
\hline \multirow[t]{2}{*}{$>1200$ employees } & 16 & $18 \%$ & 35 & $23 \%$ \\
\hline & 88 & $100 \%$ & 149 & $100 \%$ \\
\hline
\end{tabular}

\section{Methodological approach}

Responding to the research objectives, two empirical studies were conducted. In February 2014 an online survey was sent to 850 German utilities which are members of the German Association of Energy and Water Industries (BDEW). Additionally, the survey was distributed to 30 Austrian utility companies which are members of the Austrian Energy Association (Österreichs Energie e. V.). In order to acquire reliable data regarding the deployment of Facebook-based communication in the energy sector, the same companies were asked to complete the survey again after a period of twelve months, in February 2015. Ten percent of the utilities completed the survey in 2014 , including 80 German and eight Austrian companies. In 2015 the response rate grew to around 17 percent, consisting of 130 German and 19 Austrian utilities. Regarding ownership, in both years around half of the companies were entirely public. In 2014 two fifths and in 2015 one third of the companies described themselves as at least to some extent public. The majority of the companies with such mixed ownership specified their public share at more than 50 percent. Therefore most of the companies surveyed were entirely or for the most part public. In contrast, only 13 percent of the utilities in 2014 and
15 percent in 2015 indicated complete private ownership. In addition to ownership, the number of employees is used as an indicator of company size. In both years about 65 percent of the utilities have up to 600 employees, whereas around 15 percent list a workforce between 600 and 1200 employees. Only nearly 20 percent of the companies have more than 1200 employees. The above specifications of the participating utilities are summarized in Fig. 1. Concerning the proportional shares of the utilities' nationalities, ownership types and company sizes, the results of both online surveys are similar, allowing a longitudinal analysis of developments in Facebook-based communication over a oneyear period.

Bauer et al. (2012) point out that access to information is a key reason for Facebook users to become a fan of a site. Following this idea, the amount of fans was used as an indicator of communication outcomes. If the information provided is perceived as interesting, the utilities are likely to gain fans. On the other hand, if the information is not perceived as noteworthy, Facebook users might not want to become fans of a page. In this context, Pedersen et al. (2013) emphasize the importance of a stakeholder dialog. Such a dialog on Facebook requires interactivity with the various stakeholders as well as a certain frequency of com- 
Fig. 2 Addressed stakeholder (multiple choices possible)

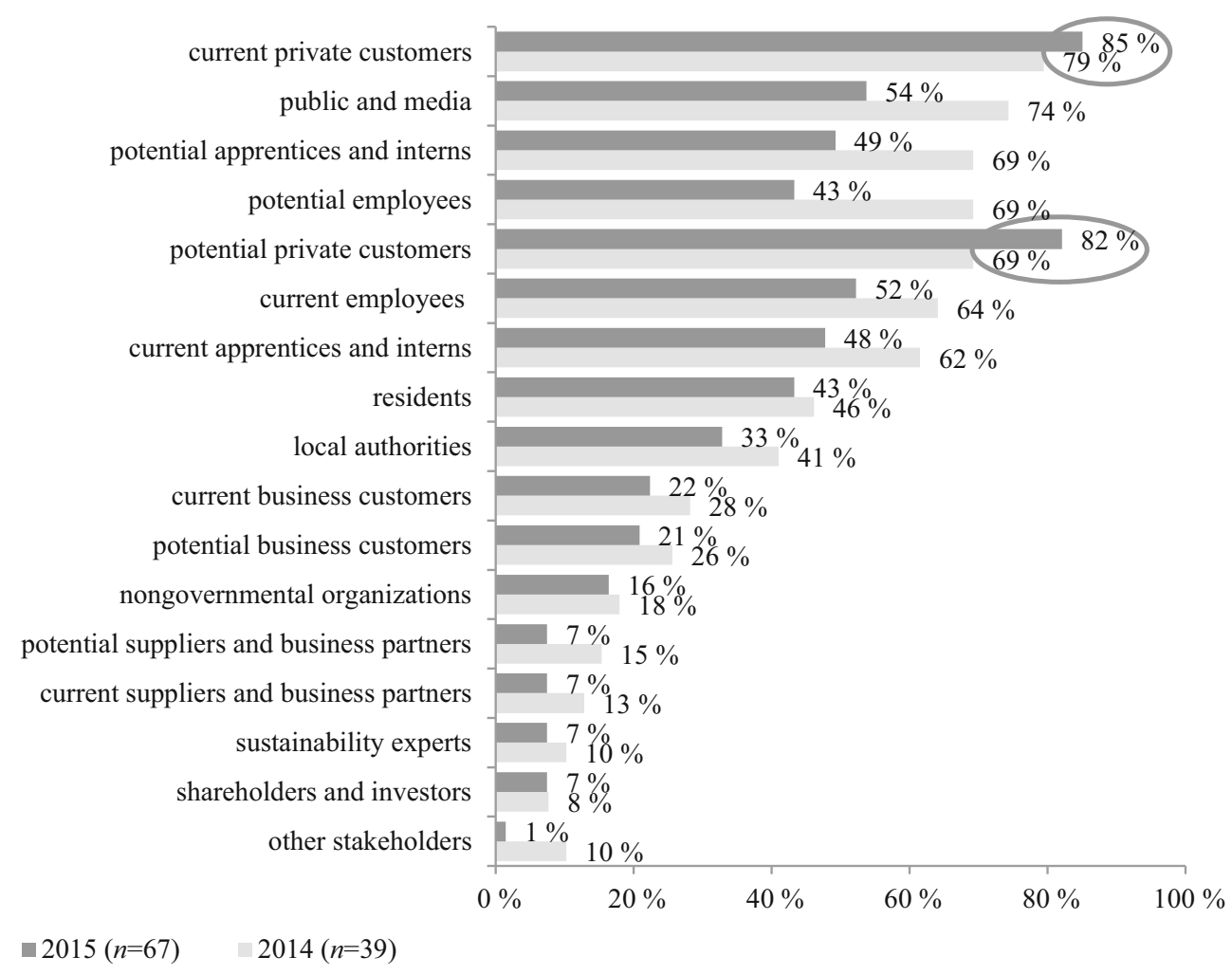

munication. Therefore, interactivity and frequency seem to be adequate indicators for the intensity of a stakeholder dialog. Both indicators are variable and can change over time. Such change could depend on the available monetary and personnel resources deployed.

\section{Empirical findings}

In 2014, out of the participating 88 utilites, a minority of 44 percent possesed a Facebook account. During the period investigated this share significantly increased to 58 percent of the 149 companies which completed the survey in 2015. Therefore, since 2015 the majority of utility companies have begun to use Facebook for stakeholder communication. In 2014, the 49 companies without an account explained their absence was due to insufficient control of the medium (55 percent), excessive workload (49 percent), insufficient knowledge of Facebook (20 percent) and excessive costs ( 2 percent). In 2015, the percentage of utilities which feared insufficient control sharply decreased to 38 percent of the responding 74 entities. Likewise, the share of companies which are concerned about insufficient knowledge of Facebook declined about 40 percent. In both years, excessive workload was constantly mentioned by nearly half of the entities without an account. In contrast, the share of utilities which explained their Facebook ab- sence on account of excessive costs increased more than five times to 11 percent in 2015 .

In 2014, the majority of the 39 utilities with an account used Facebook to reach current and potential private customers, current and potential employees, current and potential apprentices and interns as well as the general public and media. Slightly fewer than half of the companies concentrated on local authorities or residents, whereas only a minority emphasized current and potential business customers, non-governmental organizations, current and potential business partners or sustainability experts. The described stakeholder focus changed during the period investigated. In 2015, the share of utilities targeting current and potential private customers increased to more than 80 percent. In contrast, the share of companies that seek attention at other stakeholder groups sharply declined. The described developments are shown in Fig. 2.

Concerning the average frequency of postings, in 2014, 17 percent of the utilities provided information once a day, nearly half of the companies publicized information several times a week, a share of 14 percent at least once a week and 17 percent provided information several times a month. Overall the average frequency of information grew in 2015 as, for example, a higher share of companies publicized information several times a week, and even five percent of the companies provided information several times a day. Fig. 3 below illustrates the increases. 
Fig. 3 Average frequency of the provided information

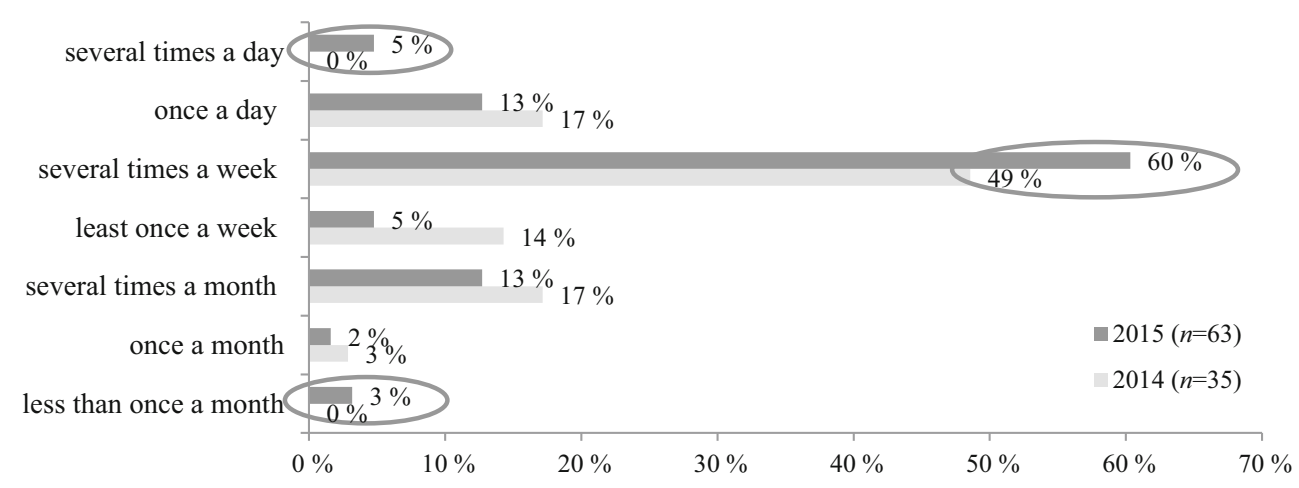

Fig. 4 Degree of interactive communication on Facebook

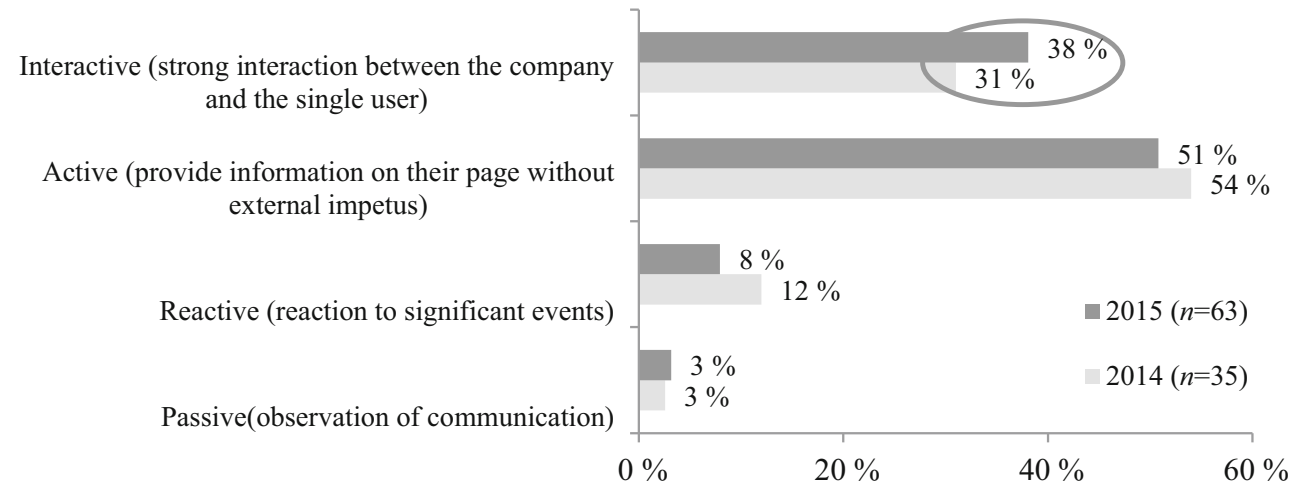

Additionally, the companies were asked to give more detailed insights into how they communicate on Facebook. In both years, most companies described their communication as interactive or active. Only a minority of utilities called their communication reactive or passive. During the period of twelve months, the share of companies with active approach to communication, which means companies that act without external impetus to provide information on their page, slightly declined from 54 to 51 percent. At the same time the share of companies using interactive communication, meaning a strong interaction between the company and the single users, rose from 31 to 38 percent. Figure 4 summarizes these findings.

As shown in figure 5, in 2014, the utilities estimated an average of 8.9 staff hours per week to administer the Facebook account. The maintenance process was mostly carried out by in-company full time personnel. In 2015, the total time deployed for the Facebook account grew about 50 percent to 13.5 staff hours per week. The time spent by companies' part-time personnel and apprentices or interns increased. Even so, most of the time was spent by incompany full-time personnel.

Concerning the financial resources, in both years, the vast majority of companies spent up to 15,000 euros annually on their Facebook account. A development can be detected as the share of companies that spend more than 15,000 euros annually grew between the years 2014 and
2015. Such increases can especially be seen for the share of utilities which invest between 45,000 and 60,000 euros (increase of 7 percent) and the companies spending more than 75,000 euros (increase of 4 percent). Figure 6 summarizes these findings.

According to Bauer et al. (2012), the amount of Facebook fans was used as an indicator for communication outcomes. This implies the idea that stakeholders only become and stay fans of a Facebook site if the utility company constantly offers interesting information and/or the possibility of a stakeholder dialog. As highlighted in figure 7 , during the year under observation the median of fans increased about 19 percent and the arithmetic average about 17 percent. When the previous consideration is applied, this could indicate that stakeholders to some extent value how utilities communicate on Facebook.

\section{Discussion}

Stakeholder theory highlights the importance of actively managing stakeholder relationships (Freeman 1984). The number of German and Austrian Facebook users is growing constantly (statista 2014a, 2014b). Utility companies seem to be aware of this relatively new opportunity for stakeholder communication as the share of utilities engaged in Facebook is increasing. The reasons for not using this 
Fig. 5 Deployed time resources for Facebook (hours/week)

\begin{tabular}{|c|c|c|c|c|c|c|c|c|}
\hline \multirow{3}{*}{$\begin{array}{l}\text { time } \\
\text { ressources }\end{array}$} & \multicolumn{4}{|c|}{2014} & \multicolumn{4}{|c|}{2015} \\
\hline & \multirow{2}{*}{$\begin{array}{l}\text { Ø Facebook- } \\
\text { working } \\
\text { hours/ week }\end{array}$} & \multirow{2}{*}{$\begin{array}{c}\text { number } \\
\text { of } \\
\text { utilities }\end{array}$} & \multicolumn{2}{|c|}{ hours/utilities } & \multirow{2}{*}{$\begin{array}{c}\text { Ø Facebook- } \\
\text { working } \\
\text { hours/week }\end{array}$} & \multirow{2}{*}{$\begin{array}{c}\text { number of } \\
\text { utilities }\end{array}$} & \multicolumn{2}{|c|}{ hours/utilities } \\
\hline & & & minimum & maximum & & & minimum & maximum \\
\hline $\begin{array}{c}\text { full-time } \\
\text { personnel }\end{array}$ & 9.0 & 25 & 1 & 30 & 13.4 & 44 & 0.25 & 80 \\
\hline $\begin{array}{l}\text { part-time } \\
\text { personnel }\end{array}$ & 2.0 & 1 & 2 & 2 & 9.1 & 10 & 0.25 & 35 \\
\hline $\begin{array}{l}\text { apprentices/ } \\
\text { interns }\end{array}$ & 7.0 & 1 & 4 & 4 & 5.3 & 3 & 7 & 2 \\
\hline $\begin{array}{c}\text { total time for } \\
\text { the whole } \\
\text { utility }\end{array}$ & 8.9 & 26 & 1 & 30 & 13.5 & 51 & 0.25 & 80 \\
\hline
\end{tabular}

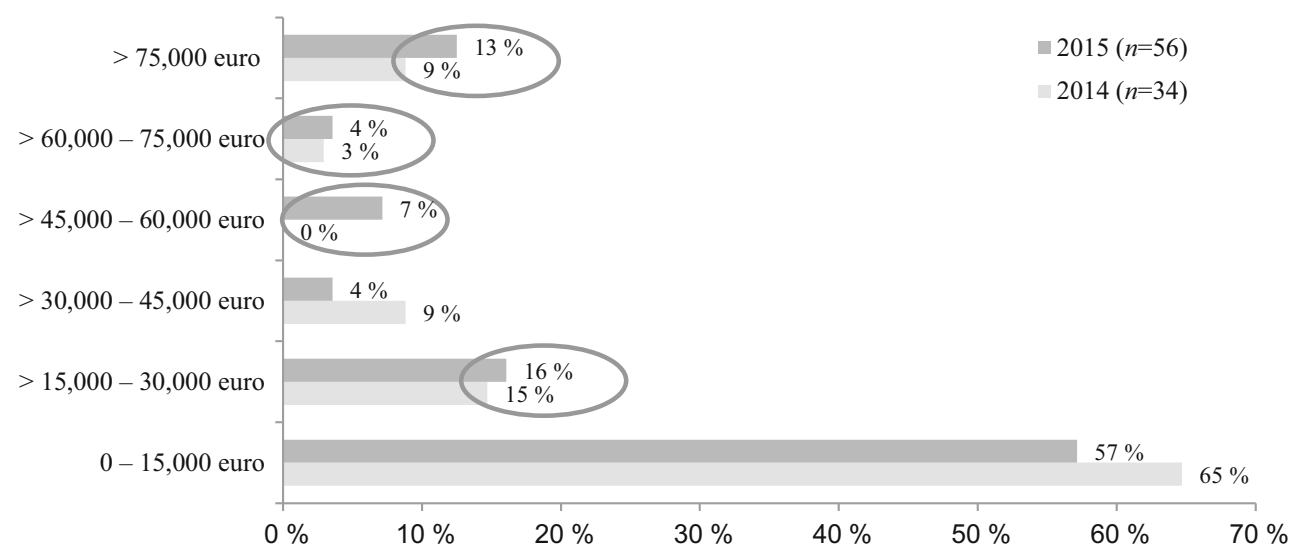

Fig. 6 Financial resources spent for the Facebook account months, the devoted time resources for Facebook increased about 50 percent and the share of companies spending more than 15,000 euros annually on the Facebook account more than 20 percent. These results emphasize the idea that more and more utilities acknowledge the increasing importance of Facebook for stakeholder communication and are willing to invest in this medium. In both years, the Facebook account is commonly supported by a company's full time employees. Only one-fourth of the companies outsourced a part of the Facebook-related work to external service providers. A reason for this could be that the stakeholder dialog might be more authentically and effectively handled by internal personnel. Bauer et al. (2012) point out that access to information is a major reason for Facebook users to become fans of a page. During the period investigated the number of fans rose. Maybe such a strong development is a consequence of an intensified stakeholder dialog, which is recommended by stakeholder theory and empirically indicated by higher information frequency and interactivity. 
Fig. 7 Amount of fans on Facebook

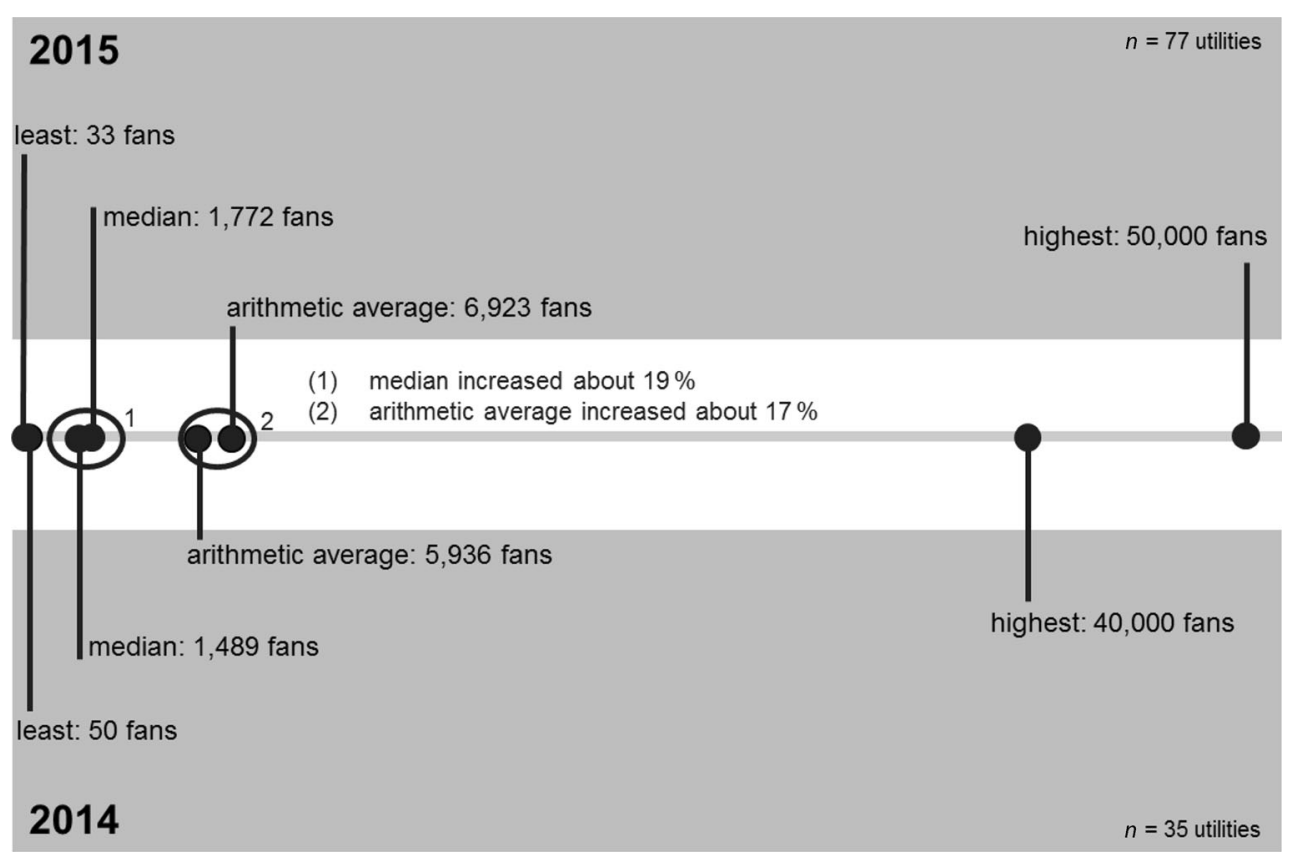

\section{Conclusion: Progress and prospects}

This article explores developments regarding the use of Facebook by German and Austrian utility companies. The findings reveal that more and more utilities are using Facebook to communicate with their stakeholders. During the twelve months investigated, utilities strengthened their communication efforts towards current and potential customers. Such a narrow focus is in contradiction to stakeholder theory, which recommends communication to a wide variety of stakeholders. Additionally, the theory emphasizes the importance of stakeholder dialog. As frequency and interactivity of communication grow, utilities seem to be following this advice. It is assumed that such communication efforts are somehow connected to the revealed increase of the invested resources and might lead to the rising amount of fans documented. Overall, the described developments indicate the growing importance of Facebook as a form of stakeholder communication. Still, this study only focusses on utility companies which are members of the German Association of Energy and Water Industries (BDEW) or the Austrian Energy Association (Österreichs Energie e. V.). The associations provide various services, such as information, to its members and therefore affect their behaviour. Companies without such memberships were not included. Consequently this study does not represent all utilities and it is only to a limited extent possible to generalize the study results for the whole energy sector. In order to generalize findings, future studies should also integrate utilities which are not members of the focused associations. Moreover, this study is limited to a period of twelve months. To more precisely determine development in communication, future studies should extend the period of investigation. The stakeholder dialog seems to be an essential aspect of Facebook communication. Future studies should more deeply focus on dialogrelated aspects. In particular interactivity seems to be an important characteristic which needs to be observed in a more differentiated way. Additional interviews with the marketing managers of utilities or surveys of the various stakeholders could generate new communication insights. It could be also interesting to look in more detail at the relationship between aspects of stakeholder dialog, such as communication frequency and interactivity, the resources invested and the communication outcome. As communication might differ in an international context, future studies could additionally focus on countries other than Germany and Austria.

Acknowledgements The author is grateful to Linda Tuttle Weidinger, B.A., instructor of English, University of Applied Sciences and University of Education, Linz, Austria, for her language assistance and proofreading.

Conflict of interest S. Martin states that there are no conflicts of interest.

Open Access This article is distributed under the terms of the Creative Commons Attribution 4.0 International License (http:// creativecommons.org/licenses/by/4.0/), which permits unrestricted use, distribution, and reproduction in any medium, provided you give appropriate credit to the original author(s) and the source, provide a link to the Creative Commons license, and indicate if changes were made. 


\section{References}

Bauer H, Toma B, Fischer D (2012) Die Facebook-Fanpage - Effektive Gestaltung und kommunikationspolitische Wirkung. Mark Rev St Gallen 29:35-41

Criado JI, Sandoval-Almazan R, Gil-Garcia JR (2013) Government innovation through social media. Gov Inf Q 30:319-326

Dechange A, Friedrich B (2013) Multiprojektmanagement in der Energiewirtschaft. In: Lau C, Dechange A, Flegel T (Hrsg) Projektmanagement im Energiebereich. Springer, Wiesbaden, S 101-124

Donaldson T, Preston LE (1995) The stakeholder theory of the corporation. Concepts, evidence, and implications. Acad Manag Rev 20:65-91

Federal Ministry of Education and Research (2014) Herausforderungen der Energiewende. http://www.buergerdialog-bmbf.de/ energietechnologien-fuer-die-zukunft/299.php. Accessed: 15 . Dec. 2014

Freeman RE (1984) Strategic management: A stakeholder approach. Cambridge University Press, Boston

Freeman RE, Evan WM (1990) Corporate governance: A stakeholder interpretation. J Behav Econ 19:337-359

Fieseler C, Hoffmann CP, Meckel M (2010) CSR 2.0 - Die Kommunikation von Nachhaltigkeit in Sozialen Medien. Mark Rev St Gallen 27:22-26

Haigh MM, Brubaker P, Whiteside E (2013) Facebook: examining the information presented and its impact on stakeholders. Corp Commun Int J 18:52-69

Hofmann S, Beverungen D, Räckers M, Becker J (2013) What makes local governments' online communications successful? Insights from a multi-method analysis of Facebook. Gov Inf Q 30:387-396

Kreutzer RT, Hinz J (2010) Möglichkeiten und Grenzen von Social Media Marketing. Working Papers No. 58. Hochschule für Wirtschaft und Recht. IMB Institute of Management Berlin, Berlin

La Rosa A (2014) Social Media and Social Movements Around the World, Lessons and Theoretical Approaches. In: Patru B, Patru M (Hrsg) Social Media in Politics Case Studies on the Political Power of Social Media. Springer, New York, S 35-47

Meijer A, Thaens M (2013) Social media strategies: Understanding the differences between North American police departments. Gov Inf Q 30:343-350

Merilainen N, Vos M (2011) Human rights organizations and online agenda setting. Corp Commun Int J 16:293-310

Mergel I (2013a) A framework for interpreting social media interactions in the public sector. Gov Inf Q 30:327-334

Mergel I (2013b) Social Media in the Public Sector. A Guide to Participation, Collaboration and Transparency in The Networked World. Wiley, San Francisco
Mergel I, Greeves B (2012) Social Media in the Public Sector Field Guide. Designing and Implementing Strategies and Policies. Wiley, San Francisco

Mergel I (2010) Government 2.0 Revisited. Social Media Strategies in the Public Sector. Pa Times Am Soc Public Adm 33:7-10

Mossberger K, Yonghong W, Crawford J (2013) Connecting citizens and local governments? Social media and interactivity in major U.S. cities. Gov Inf Q 30:351-358

Oliveira GHM, Welch EW (2013) Social media use in local government: Linkage of technology, task, and organizational context. Gov Inf Q 30:397-405

Pedersen AGJ, Lagergaard D, Sanderhoff M (2013) Der Stakeholderdialog in Geschäftsberichten: Eine Analyse der dargestellten Dialogbereitschaft europäischer Energieunternehmen. uwf 21:97-104

Pietsch G (2012) Social Media in Unternehmen. Entwicklungsstand und Entwicklungspotenzial. In: Schulten M, Mertens A, Horx A (Hrsg) Social Branding. Strategien - Praxisbeispiele - Perspektiven. Gabler Verlag, Wiesbaden, S 451-466

Schulten M (2012) Return on Social Branding. In: Schulten M, Mertens A, Horx A (Hrsg) Social Branding. Strategien - Praxisbeispiele - Perspektiven. Gabler Verlag, Wiesbaden, S 371-389

Spillecke D (2013) Social Media ROI. Erfolge messen in sozialen Netzwerken. Control Manag Rev 57:26-35

Statista (2014a) Anzahl der aktiven Nutzer von Facebook in Deutschland von Januar 2010 bis Mai 2014 (in Millionen). http://de. statista.com/statistik/daten/studie/70189/umfrage/nutzer-vonfacebook-in-deutschland-seit-2009/. Accessed: 22. Oct. 2015

Statista (2014b) Anzahl der Nutzer von Facebook in Österreich von September 2012 bis September 2015 (in Millionen). http:// de.statista.com/statistik/daten/studie/296115/umfrage/facebooknutzer-in-oesterreich/. Accessed: 22. Nov. 2015

Vicente MR, Novo A (2014) An empirical analysis of e-participation. The role of social networks and e-government over citizens' online engagement. Gov Inf Q 31:379-387

Wallsten K (2007) Agenda setting and the blogosphere. an analysis of the relationship between mainstream media and political blogs. Rev Policy Res 24:567-587

Wall F, Greiling D (2011) Accounting information for managerial decision-making in shareholder management versus stakeholder management. Rev Manag Sci 5:91-135

Wingenter T (2013) Bewertung von Social Media. Mehr als „Return On Ignorance“? Control Manag Rev 57:58-65

Witt P (2013) Innovationsmanagement in Energieversorgungsunternehmen. In: Lau C, Dechange A, Flegel T (Hrsg) Projektmanagement im Energiebereich. Springer, Wiesbaden, S 53-68

Yang H-L, Lin C-L (2013) Why do people stick to Facebook web site? A value theory-based view. Inf Technol People 27:21-37 